\title{
Microbiological investigations after the "Bravo" blowout (Ekofisk Oil Field, North Sea)
}

\author{
W. Gunkel ${ }^{1}$, S. Pedersen ${ }^{2}$, I. Dundas ${ }^{3} \&$ K. Eimhjellen ${ }^{2}$ \\ ${ }^{1}$ Biologische Anstalt Helgoland, Meeresstation Helgoland, D-2192 Helgoland, \\ Federal Republic of Germany \\ ${ }^{2}$ Department of Biochemistry, Norwegian Institute of Technology, \\ N-7034 Trondheim - NTE, Norway \\ ${ }^{3}$ Department of General Microbiology, University of Bergen, N-5014 Bergen, Norway
}

\begin{abstract}
Following the accident in 1977 at an offshore oil producing platform in the Ekofisk oil field (North Sea) an estimated amount of 13000-15000 tons of oil polluted the sea. Microbiological investigations were conducted one to five weeks after the blowout and compared with data collected in the same area during the years before. Bacterial numbers in the water were fairly low. In the floating oil particles, however, extremely high values were obtained $\left(2 \times 10^{11}\right.$ heterotrophic bacteria $1^{-1}$ and $5 \times 10^{10}$ oil degrading bacteria $1^{-1}$ ). The data on oxygen consumption gave markedly different results indicating that the oil degradation potential of the water seemed to vary widely from one station to another. The greatest increase in oxygen consumption (following the addition of oil to the bottles) occurred in samples taken at the station where oil particles from the blowout were observed floating on the surface. This indicates a higher oil degradation potential.
\end{abstract}

\section{INTRODUCTION}

\section{The accident in the Ekofisk area}

On April 22, 1977 a blowout started at the oil production platform "Bravo", situated $56^{\circ} 33^{\prime} \mathrm{N}, 03^{\circ} 12.2^{\prime} \mathrm{E}$ within the Ekofisk area in the North Sea. The blowout resulted in uncontrolled discharges of crude oil through the open pipe $20 \mathrm{~m}$ above sea surface at an estimated rate of $3000-4000$ tons per day. The oil was blown another $30 \mathrm{~m}$ into the air and sprayed over the sea surface. Depending on wind forces and the movement of surface waters during the following days, the resulting oil slick attained varying shapes, patches of about $1-\mathrm{cm}$ thick oil slicks interchanging with areas of thin film and streamers of oil. Ekofisk crude oil is light-flowing and has a high content of volatile aromatic hydrocarbons. The blowout lasted $7 \frac{1}{2}$ days until, after several attempts, an expert team succeeded in capping the well on April 30. The remaining oil slick, estimated at some 13000-15000 tons, had then spread over an area of about $4000 \mathrm{~km}^{2}$ interspersed with areas of seemingly unpolluted waters (Bratberg, 1977).

At the statutory meeting of ICES at Reykjavik in 1977 some scientists, involved in research related to the environmental consequences of the Ekofisk "Bravo" blowout, met and agreed that a joint publication should be prepared. On invitation and under the 
chairmanship of Dr. G. Berge, Institute of Marine Research, Bergen, Norway, 25 scientists from several institutes of North Sea countries met from February 27 to March 3, 1978 at Vatnahalsen, Norway to discuss the results of their work after the blowout. Different working groups started to prepare chapters which focussed on the effects of oil on the living marine resources, and also physical and chemical aspects including drift, dispersions and weathering. For reasons outside the responsibility of Dr. Berge the planned publication of a joint report did not materialize. In the following, the proposed contribution on microorganisms and oil degradation is presented. G. Berge's efforts in preparing this contribution are very much appreciated.

\section{General remarks and objective}

Bacteria, yeasts and fungi are normal members of the marine biota. These microorganisms are active in degrading organic materials introduced to, or produced in, the sea. Concomitant with this degradation they also liberate inorganic nutrients bound in the organic material. The utilization of inorganic nutrients by marine phytoplankton in the course of photosynthetic primary production exceeds the amounts of inorganic nutrients immediately available in the surface water. It is partly sustained through the microbial mineralization of organic material.

Addition of organic material to sea water will normally cause an increase in bacterial activity. Hydrocarbon production and hydrocarbon degradation are specialized but normal activities of marine microbial biotas. An oil spill may represent a drastic change in the quantity of organic material available for marine microorganisms. One may assume that immediately after an oil spill some members of the microbial biota may be killed due to toxic qualities or harmful concentrations of some oil components. Many other microorganisms will respond to the oil spill as they would to any increase in organic content of the sea water.

By measuring the oil-degrading activity of the microbial population one may assess at what rate oil can be removed from the environment by this mechanism. One may also obtain an estimate of oil degradation rates indirectly by measuring the number of oildegrading organisms in the water. Direct measurements are made difficult by the naturally low rates of bacterial oil degradation and by limitations due to low concentrations of all components. The use of isotope-labelled model hydrocarbons may partly solve this difficulty. The numbers of bacterial cells estimated by direct microscopic counting, the numbers of microorganisms able to grow on complex organic substances or the rate of oxygen consumption by the microbial flora may all be correlated to the oil degradation rates in the water. The proper relations between these parameters are difficult to assess and may be masked by several uncontrolled or unknown factors.

The difficulties in obtaining direct measurements of oil degradation rates emphasized the importance of determining the correlation factors for the more easily obtained indirect measurements, such as bacterial numbers or oxygen consumption. The effect of environmental factors such as temperature, light intensity or nutrient concentrations on the activities of the bacterial flora must be determined if one is to correlate a bacterial population with its biochemical activity.

Different methods have been used in the present investigations to assess the oil degradation activity, as well as the effect of the oil expelled by the blowout upon the 
general heterotrophic microbial organisms in the affected areas. Most of these methods are indirect measurements of activity, and are mainly based upon microbiological enumeration. Reliable direct methods for measuring oil degradation are not available. There is, however, some advantage in using the indirect methods in that the results from the present investigations can be directly compared with baseline studies already performed over several years in the North Sea and specifically in the area surrounding Ekofisk.

In a region like the North Sea, subjected to strong increases in exploration, production, loading and shipping of oil, a steady increase in pollution due to chronic spillage and to major accidents is to be expected. In order to obtain baseline information for further work, ecological investigations were initiated in 1975 covering the open North Sea, with main emphasis on the microbiological and chemical aspects of marine oil pollution. The Biologische Anstalt Helgoland (BAH), FRG, furnished the research vessel "Friedrich Heincke". Scientists and technicians from the BAH together with colleagues from Norway, USA and the UK, participated in cruises in 1975 and 1976. Some of the results have been reported elsewhere (Oppenheimer et al., 1977; Gunkel et al., 1980; Gunkel, W., in Jahresbericht, Biologische Anstalt Helgoland 1976, pp. 40-44; 1977, pp. $36-40 ; 1978$, pp. 33-36; Gassmann, G., in Jahresbericht, Biologische Anstalt Helgoland, 1976 , p. $40 ; 1977$, p. 39; 1978 , pp. 36-38).

Scientists from Germany (FRG), Belgium, Norway and Sweden participated in the 1977 cruise of "Friedrich Heincke" which closely followed the cruise tracks of 1975 and 1976. The cruise tracks and stations numbers for the "Friedrich Heincke" cruises in 1975 and 1977 are shown in Figures 1 and 2. The cruise track and station grid system for the "G. O. Sars" 1977 cruise are shown in Figure 3.

The results presented in this chapter were obtained during the cruises with "G. $O$. Sars" (27. 4.-2. 5. 1977) and "Friedrich Heincke" (11. 5,-20,5.1977) and are compared with data obtained in 1975 and 1976.

As sampling time and sampling methods may influence the results obtained, the methods and results obtained from the vessel "G. O. Sars" and "Friedrich Heincke" are identified by the initials GOS and FH respectively in the following sections.

\section{METHODS}

The 5 and $10 \mathrm{~m}$ depth samples (GOS) were collected by Niskin flasks, and a sterile ZoBell sampler was used for the 2 and $10 \mathrm{~m}$ depths (FH). The surface water was sampled using a bucket (GOS) or a special skimming device sampling the upper $5 \mathrm{~cm}$ of the surface water and pumping it on board through a teflon tube using a peristaltic pump $(\mathrm{FH})$.

Bacterial numbers were determined using several different methods:

(1) "Oil-degrading bacteria, membranefiltration technique" (MFT) GOS. Dilution series $\left(10^{-1}\right.$ to $\left.10^{-6}\right)$ were set up, and 20,10 and $1 \mathrm{ml}$ of undiluted water samples and $1 \mathrm{ml}$ of each diluted sample were filtered through membrane filters (Selectron, $0.45 \mathrm{~mm}$ pore diameter). The membrane filters were placed in petri dishes on top of cellulose pads soaked with a sea water/mineral salts medium. A mixture of different oil constituents $\left(n-C_{14}, n-C_{16}\right.$ and $n-C_{18}$ alkanes plus motor oil SAE 50 in equal amounts, total $0.1 \% \mathrm{w} / \mathrm{v}$ ) was used as the carbon and energy source. The filters 


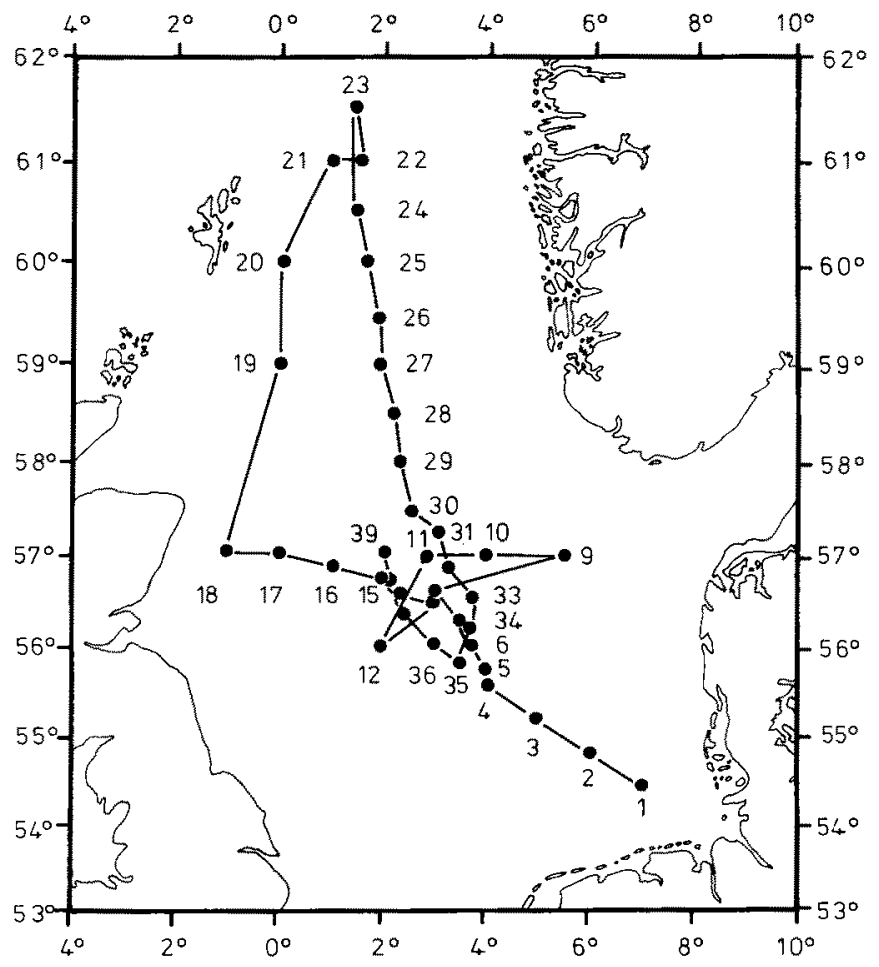

Fig. 1. Courses and stations for RV "Friedrich Heincke" 28 July - 14. August 1975

were incubated at $10^{\circ} \mathrm{C}$ for a period of $1-3$ weeks. Results by this technique are referred to as "oil-degrading bacteria (MFT)" and "oil-degrading fungi (MFT)".

(2) "Direct microbial counts", FH. Microbial counts were obtained by direct epifluorescence microscopy of stained and filtered samples (Indrebø \& Dundas, 1977). The numbers obtained by this method represent the total sum of active, resting and dead microorganisms. These results will be referred to as "direct microbial counts",

Bacterial numbers were also determined by standard techniques which have been used in our laboratories for many years (Gunkel \& Trekel, 1967; Gunkel \& Rheinheimer, 1972; Gunkel, 1973; Gunkel et al, 1980; Gunkel, 1968). The numbers of colonies formed in "pour plates" with Agar Sea Water medium $2216 \mathrm{E}$ after ZoBell were determined after 3 weeks incubation at $18^{\circ} \mathrm{C}$. Results by this technique are referred to as "heterotrophic bacteria".

(3) "Oil-degrading bacteria, most probable number techni$q u e^{\prime \prime}, F H$. This method is based on the observations of growth on oil in liquid mineral medium (aged sea water enriched with inorganic nitrogen and phosphate salts). The only carbon and energy source was a mixture of weathered Ekofisk crude and diesel fuel oil.

Decadic dilutions of water samples were inoculated in triplicate. Growth was indicated by turbidity in the media after 8 weeks incubation at $18^{\circ} \mathrm{C}$. Numbers of 


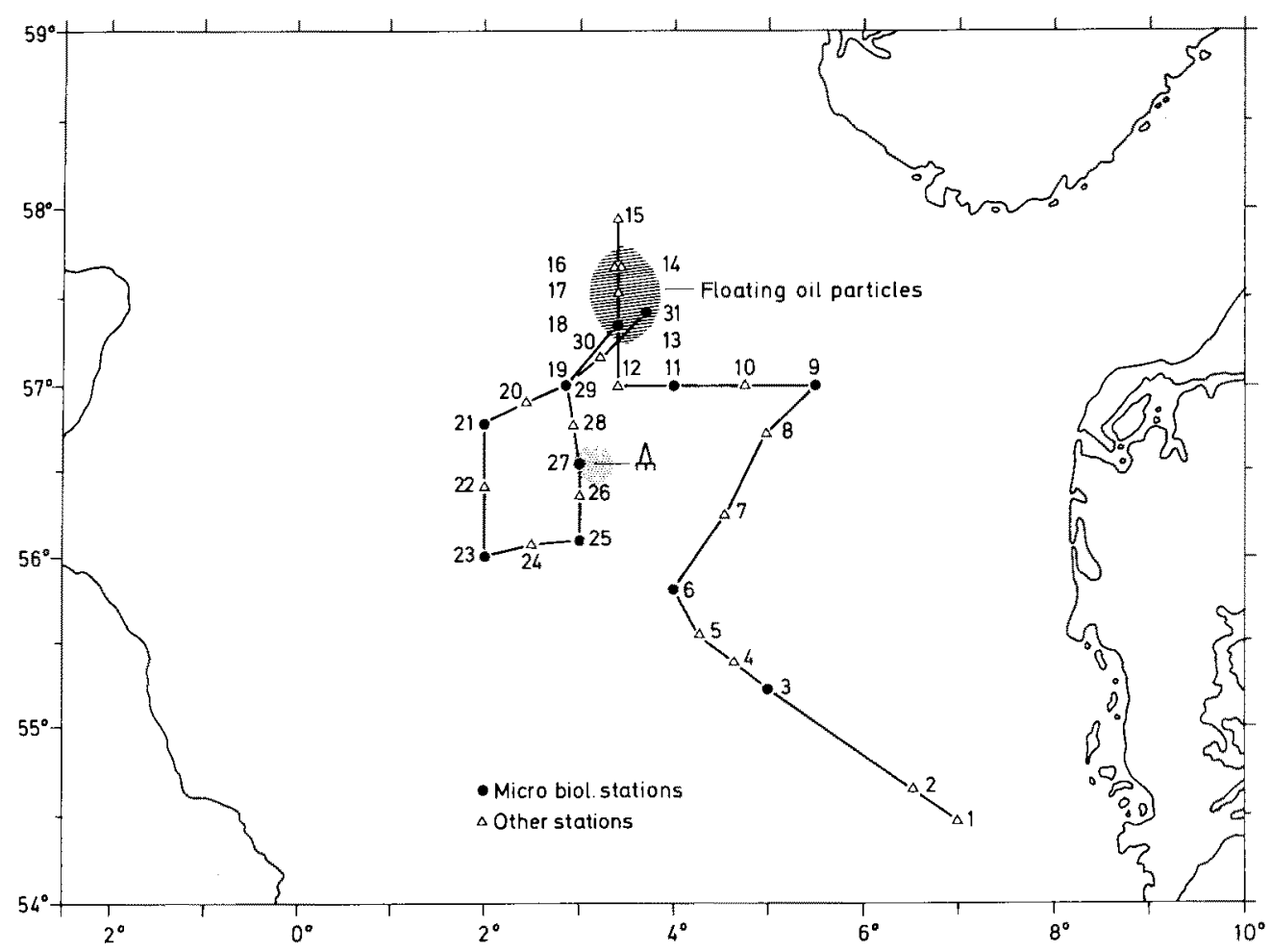

Fig. 2. Courses and stations for RV "Friedrich Heincke" 11 May - 20 May 1977
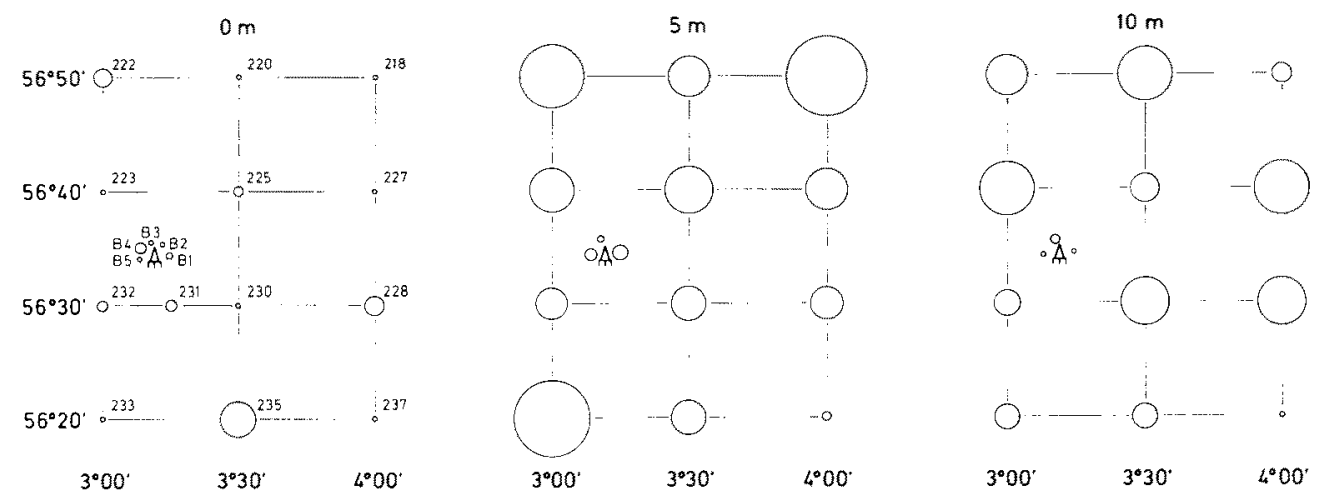

Fig. 3. Stations for RV "G. O. Sars" with relative stock sizes of oil-degrading bacteria (circles) 5-8 days after commencement of the blowout. (Numerical values in Table 1)

bacteria in the original sample were calculated using the "most probable number" tables. Results by this technique are referred to as "oil-degrading bacteria (MPN)".

(4) "Oxygen consumption in oil polluted water" FH. At each station, six half-litre bottles were completely filled with surface water. To each of three 
bottles $100 \mathrm{mg}$ of weathered Ekofisk crude was added. All six bottles were incubated in the dark at $18^{\circ} \mathrm{C}$. The oxygen content in parallel bottles, with and without added oil, was determined after 5, 10 and 15 days, using a modified (after Kalle) Winkler technique. Results by this technique are referred to as "oxygen consumption".

\section{RESULTS}

The numbers of oil-degrading bacteria and oil-degrading fungi in water samples from the Ekofisk-"Bravo" area, as found 5-8 days after the blowout, are given with the cruise grid in Figure 3 and Table 1.

Table 1. Numbers of oil-degrading bacteria and fungi in water samples from different depths in the Ekofisk-"Bravo" area, 5-8 days after the blowout (Values are given as numbers $\times 1^{-1}$ ). The station numbers refer to positions given in Figure 3

\begin{tabular}{|ccccccr|}
\hline \multirow{2}{*}{ Station } & \multicolumn{2}{c}{$0 \mathrm{~m}$} & \multicolumn{2}{c}{$5 \mathrm{~m}$} & \multicolumn{2}{c|}{$10 \mathrm{~m}$} \\
& Bacteria & Fungi & Bacteria & Fungi & Bacteria & Fungi \\
\hline & 50 & $<50$ & $3.4 \times 10^{4}$ & $<50$ & $2.0 \times 10^{3}$ & $<50$ \\
218 & 50 & $<50$ & $7.8 \times 10^{3}$ & $<50$ & $1.4 \times 10^{4}$ & $<50$ \\
220 & $1.4 \times 10^{3}$ & $<50$ & $2.0 \times 10^{4}$ & $1.4 \times 10^{3}$ & $8.0 \times 10^{3}$ & 50 \\
222 & 50 & $<50$ & $1.0 \times 10^{4}$ & $<50$ & $1.4 \times 10^{4}$ & $<50$ \\
223 & $6.0 \times 10^{2}$ & $1.4 \times 10^{2}$ & $1.1 \times 10^{4}$ & $<50$ & $4.3 \times 10^{3}$ & $<50$ \\
225 & $1.4 \times 10^{2}$ & $<50$ & $8.7 \times 10^{3}$ & 50 & $1.4 \times 10^{4}$ & $<50$ \\
227 & $2.0 \times 10^{3}$ & $<50$ & $5.9 \times 10^{3}$ & $<50$ & $1.1 \times 10^{4}$ & 50 \\
228 & 50 & $<50$ & $5.9 \times 10^{3}$ & $<50$ & $1.1 \times 10^{4}$ & $<50$ \\
230 & $5.4 \times 10^{2}$ & 50 & & & & \\
231 & $2.0 \times 10^{2}$ & $<50$ & $1.1 \times 10^{3}$ & 50 & $1.4 \times 10^{2}$ & $<50$ \\
B 1 & 50 & $<50$ & & & & \\
B 2 & 50 & $<50$ & $2.0 \times 10^{2}$ & $2.8 \times 10^{2}$ & $4.0 \times 10^{2}$ & $<50$ \\
B 3 & $6.0 \times 10^{2}$ & $<50$ & & & & \\
B 4 & 50 & $<50$ & $6.7 \times 10^{2}$ & $6.7 \times 10^{2}$ & 50 & $<50$ \\
B 5 & $7.4 \times 10^{2}$ & $1.6 \times 10^{3}$ & $4.9 \times 10^{3}$ & $<50$ & $3.8 \times 10^{3}$ & $<50$ \\
232 & $1.4 \times 10^{2}$ & $<50$ & $2.7 \times 10^{4}$ & $1.6 \times 10^{3}$ & $3.0 \times 10^{3}$ & 50 \\
233 & $6.0 \times 10^{3}$ & 50 & $5.3 \times 10^{3}$ & $<50$ & $3.0 \times 10^{3}$ & $<50$ \\
235 & $1.4 \times 10^{2}$ & $<50$ & $4.0 \times 10^{2}$ & $<50$ & $<50$ & $<50$ \\
237 & & & & & & \\
\hline
\end{tabular}

Two features are evident from these data. Firstly, the concentration of oil-degrading bacteria (MFT) in the surface samples was, in general, lower than in the samples from 5 or $10 \mathrm{~m}$ depths. Secondly, the numbers found in samples very close to the "Bravo" platform itself were quite low.

The numbers of heterotrophic bacteria, of oil-degrading bacteria and of bacteria observable by epifluorescence microscopy, found in water samples from the North Sea -"Bravo" area, 3-4 weeks after the blowout, are given in Table 2. The station numbers refer to the positions given on the cruise grid in Figure 2. The same data for heterotrophic bacteria at the surface and at $10 \mathrm{~m}$ are plotted with the cruise grid in Figure $4 \mathrm{a}$. The percentage of oil-degrading bacteria and of heterotrophic bacteria at the surface and at $10 \mathrm{~m}$ are plotted onto the cruise grid in Figure $4 \mathrm{~b}$. The numbers of heterotrophic bacteria were in all cases higher at the surface than at $10 \mathrm{~m}$. 
The "Bravo" blowout

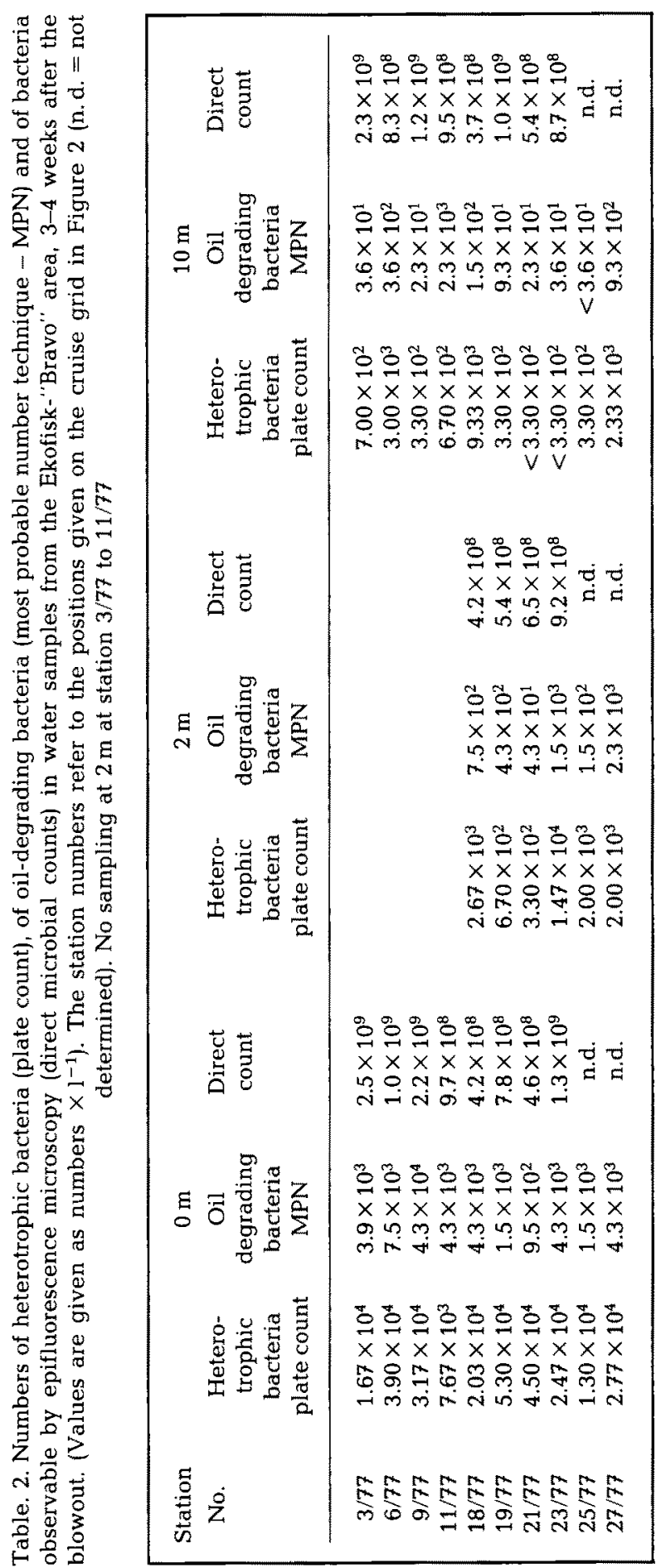



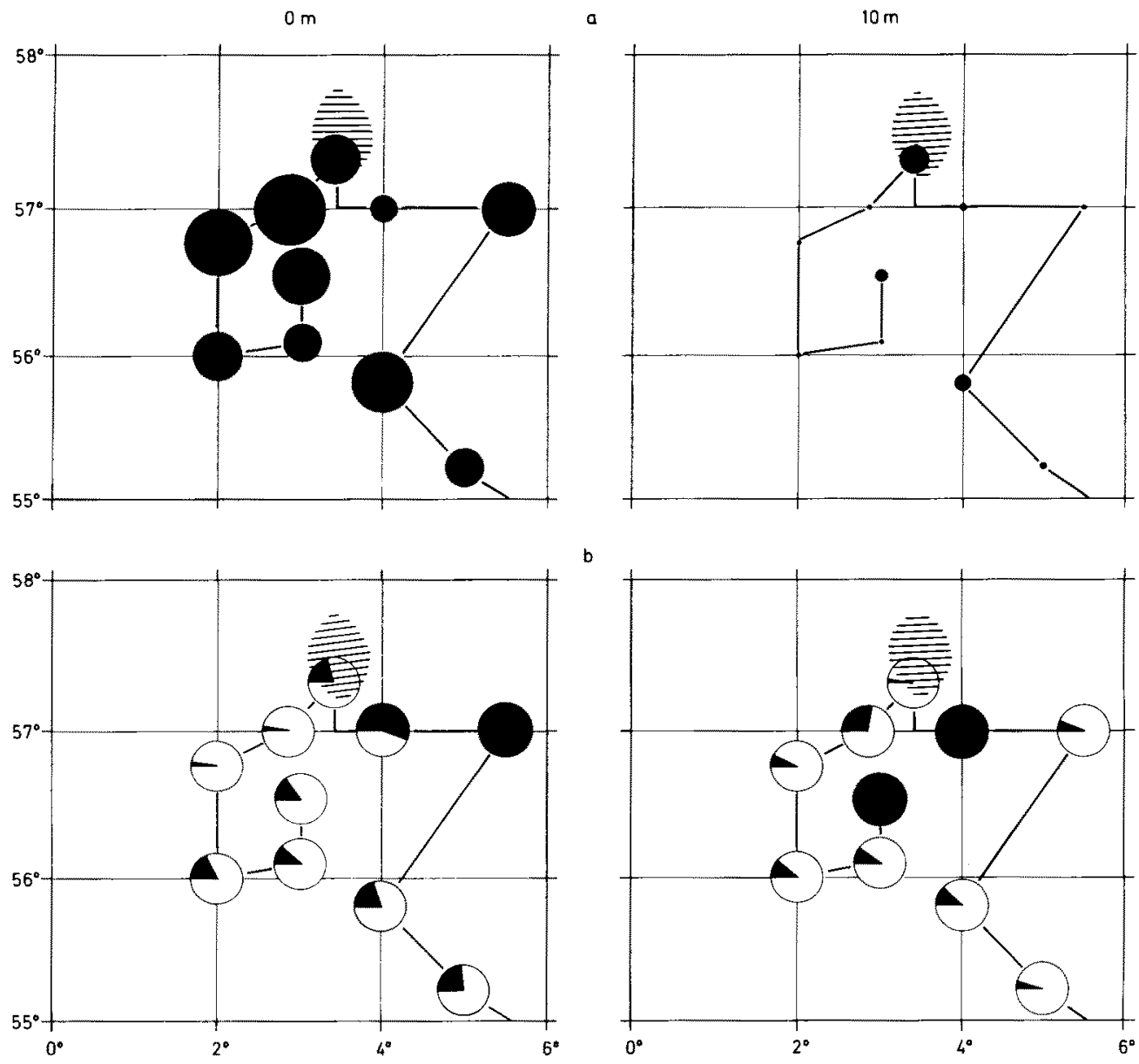

Fig. 4. Stocks of heterotrophic bacteria (upper grids) and share of oil-degrading bacteria (lower grids), 3-4 weeks after the blowout. (Numerical values in Table 2)

During the FH cruise in 1977, floating oil particles were only found in an area north of the cruise track followed in 1976 and 1975. The oil particles had a size of about $0.5 \mathrm{~cm}$. They formed "wind-rows" - about $100 \mathrm{~m}$ long and 1 to $2 \mathrm{~m}$ wide. Such wind-rows were invariably separated by at least 50 to $100 \mathrm{~m}$ of water devoid of visible oil particles. Microscopic investigation of these oil particles indicated that they constituted a stable oil-in-water emulsion containing great numbers of the diatom Rhizosolenia sp. Microbial analysis showed that the oil particles contained $2 \times 10^{11}$ heterotrophic and $5 \times 10^{10}$ oil-degrading bacteria per liter oil. This is about seven orders of magnitude higher than the bacterial numbers found for the surrounding water.

The results of the oxygen consumption experiments are shown in Figure 5. In all bottles a significant decrease in oxygen content was observed. In 20 out of 24 pairs of bottles, oxygen consumption was significantly enhanced by the addition of oil. The greatest enhancement was found in water from station $18 / 77_{\text {; }}$ it was at this station that 


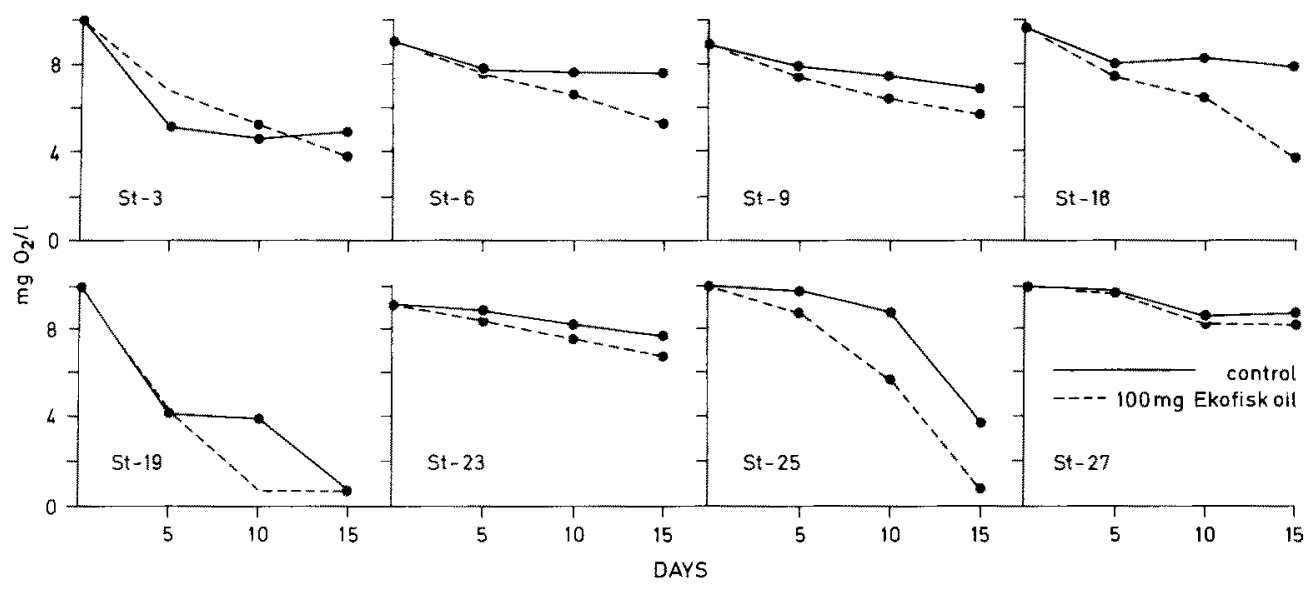

Fig. 5. Oxygen consumption in surface water at different stations 3-4 weeks after the blowout. oxygen consumption in unsupplemented water; - - - oxygen consumption in water supplemented with Ekofisk crude weathered oil

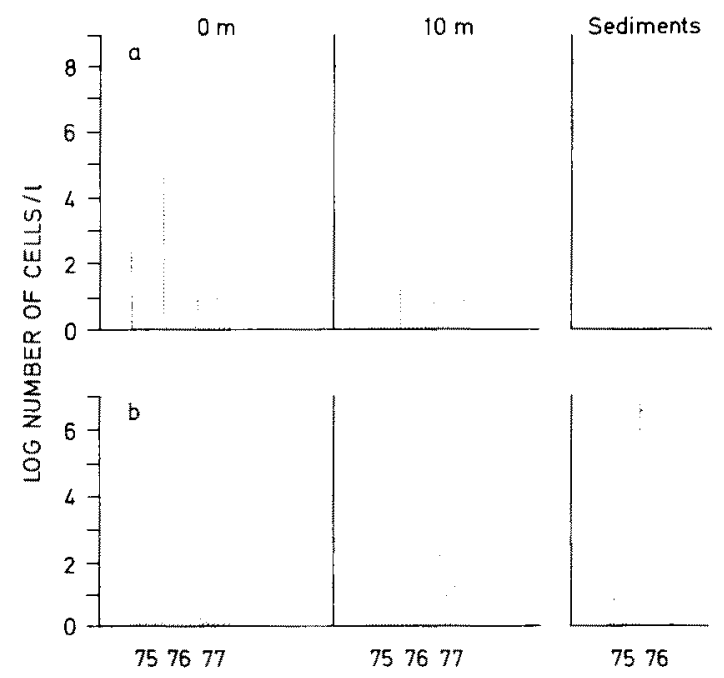

Fig. 6. Average number of (a) heterotrophic and (b) oil degrading bacteria (MPN), during the 1975, 1976 and 1977 observations from RV "Friedrich Heincke" in the North Sea

floating oil particles from the blowout were observed. The enhancement found in water collected very close to the "Bravo" platform, at station 27/77, was minimal.

A considerable part of the bacteriological work done during the three cruises by RV "Friedrich Heincke" in 1975, 1976 and 1977 is compiled in Figure 6. This figure shows the mean values obtained in the North Sea for heterotrophic bacteria and oil-degrading bacteria in the surface water, at $10 \mathrm{~m}$, and in the surface layer of the sediment. No data for the bacteria in the sediment are available for 1977 . The data are presented as the log of the bacterial count per liter of sample. The numbers of bacteria in the sediments were 
several orders of magnitude higher than those of the overlying water. The numbers of bacteria in the surface water were consistently higher than the numbers observed at $10 \mathrm{~m}$. Furthermore, the number of bacteria able to grow on complex organic media, i.e. heterotrophic bacteria, was always greater than the number of oil-degrading bacteria for the same samples.

\section{DISCUSSION}

The results to be discussed were obtained by different sampling procedures at different times and investigated by different methods. It is accordingly difficult to draw general conclusions, and part of the discussion may only be valid in relation to the specific set of data being discussed.

The bacterial numbers found in 1976 were in all cases higher than those found in 1975 (Fig. 6). This also applies to the concentration of hydrocarbons in the water (Gassmann, G., in Jahresbericht, Biologische Anstalt Helgoland, 1978, p. 38). After the blowout in 1977 one might have expected an appreciable increase in bacterial numbers, but the opposite was found to be true. The average bacterial numbers found during the "Friedrich Heincke" cruise in 1977 were even lower than those recorded in 1975. Even the average hydrocarbon concentrations in the water were lower than those found in 1976. These observations indicate that conditions affecting seasonal variations may be more important than other factors in determining the size of bacterial populations at sea.

The numbers of oil-degrading bacteria in the surface layer $(0-20 \mathrm{~cm})$ at different locations in the Ekofisk-"Bravo" area, as presented in Table 1 and Figure 3, were considerably lower than the numbers obtained for oil-degrading bacteria in the same general area in 1975 and 1976 (Fig. 6) and in 1977 (Table 2).

Before discussing possible environmental causes for the observed deviations from an expected "normal" microbiological condition in the Ekofisk area after the blowout, it is important also to be aware of the differences in sampling methods and culturing techniques used, both with regard to the present investigation, as well as other investigations referred to in this discussion.

While Gunkel et al. used a surface skimming device (Oppenheimer et al., 1977), taking water from the uppermost $5 \mathrm{~cm}$ layer over a fairly large surface area, the surface sampling from "G. $O$. Sars" was done using a bucket, which made reproducible sampling rather difficult. It was also impossible to ascertain whether any of the surface film was collected in the sampling bucket. The question is of importance because there is experimental evidence that oil-degrading bacteria tend to become concentrated in the lipophilic surface film (Gunkel, unpublished results).

The surprisingly low numbers of oil-degrading bacteria (MFT) found in the surface samples (Fig. 3) may have been due to one of several causes, ranging from possible toxic effects of the recent and massive oil spill to selective adsorption of the bacteria onto an oil film which was not captured during the bucket sampling procedure. The consistency of the results does, however, make this possibility less likely. It is also possible that any anti-corrosion or anti-scaling additives added to the "Bravo" well prior to the blowout might have an effect on the microbial flora.

The numbers of oil-degrading fungi (Table 1) were in all cases quite low. The observed microbial counts (Table 2) were of the same order as commonly observed for unpolluted waters from the North Sea. 
The data on oxygen consumption (Fig. 5) gave markedly different results for different sampling stations, indicating seemingly that the oil-degrading potential of the water varied widely from one station to another. It is indicative that the greatest increase in oxygen consumption following addition of oil to the sample (e.g. the greatest oil degradation potential) was found for the samples taken at the station where oil particles from the blowout were observed floating on the surface. On the other hand, the increase in oxygen consumption following oil addition was not correlated to the numbers obtained for "oil-degrading bacteria" (MPN). Station 9/77 (Fig. 5) had a tenfold higher number of oil-degrading bacteria than station 10/77 (Table 2), but the latter sample exhibited the highest oxygen consumption of the two.

\section{TENTATIVE GENERAL CONCLUSIONS}

Microbiological data obtained over several years in the North Sea are available for comparison with the data obtained after the "Bravo" blowout. From such comparisons one tends to conclude that hydrological conditions and seasonal climatic variations may be of equal significance to the oil supply itself in determining the size of the bacterial populations and their activities. The validity of such a conclusion may be limited to an oil spill occurring under similar conditions as the "Bravo" spill. The quantitative correlations between bacterial numbers and oil degradation rates are difficult to establish. In correlating the microbial numbers, obtained by different methods, one may get an impression of the relative oil degradation rates in different samples. The higher percentage of oil-degrading bacteria found in 1975 and 1976 in samples from stations close to the Ekofisk area (Gunkel et al., 1980) indicate a higher rate of oil degradation in this area compared to other regions of the North Sea. The high numbers of oil-degrading bacteria found after the "Bravo" blowout may thus to a greater extent be due to chronic oil pollution in this area rather than to the "Bravo" spill itself.

Since the actual hydrological conditions seem to be of major importance with regard to bacterial numbers and activities, it is recommended that all microbiological methods used should be extensively employed immediately after an oil spill in a non-affected area close to the spill. Data from such areas would serve as actual baseline for data obtained within the spill. The bacterial numbers found in oil particles (oil-in-water emulsions) after the spill indicate that more work should be directed towards studying microbial activities in the oil itself.

Further development of direct methods for measuring actual microbial rates of oil degradation is urgently needed. Methods based on degradation of isotopelabelled hydrocarbons, on hydrocarbon-dependent oxygen consumption by microorganisms, and on degradation products of hydrocarbons seem most promising. Work is also needed in establishing correlation factors between indirect methods of measurement of oil degradation, such as microbial numbers, and the actual degradation rates in situ.

Until satisfactory direct methods for measuring oil degradation have been developed, the use of several indirect methods, preferably on the same samples, may give useful inferences about the oil degradation potential of the water. It is desirable that sampling methods and sampling depths if possible be standardized for microbiological investigations during further oil spills. 


\section{LITERATURE CITED}

Bratberg, E., 1977. The Bravo Blow Out. A report on marine research activities April 23 to May 5 1977 including some preliminary results. Fisken og Havet. - Rapp. Meldr Fisk. Direct. Havforskningsinst. Bergen (Ser. B) 5, 1-41.

Gunkel, W. \& Trekel, H. H., 1967. Zur Methodik der quantitativen Erfassung ölabbauender Bakterien in verölten Sedimenten und Böden, Ol-Wasser-Gemischen, Olen und teerartigen Substanzen. - Helgoländer wiss. Meeresunters. 16, 336-348.

Gunkel, W., 1968. Bacteriological investigations of oil polluted sediments from the Cornish coast following the "Torrey Canyon" disaster. - Fld Stud. 2 (Suppl.), 151-158.

Gunkel, W. \& Rheinheimer, G., 1972. Bacteria. In: Research methods in marine biology. Ed. by C. Schlieper. Sidgwick \& Jackson, London, 156-175.

Gunkel, W., 1973. Distribution and abundance of oil-oxidizing bacteria in the North Sea. In: The microbial degradation of oil pollutants. Ed. by D. G. Ahearn \& S. P. Meyers. Louisiana State Univ., Baton Rouge, L.A., 127-129.

Gunkel, W., Gassmann, G., Oppenheimer, C. H. \& Dundas, I., 1980. Preliminary results of baseline studies of hydrocarbons and bacteria in the North Sea: 1975, 1976 and 1977. In: Ponencias del simposio internacionale: Resistencia a los antibioticos y microbiologia marina. Santiago de Compostela, 223-247.

Indreba, G. \& Dundas, 1., 1977. Microbial counts in the Ekofisk Area of the North Sea. - C.M./ICES, E55.

Jahresbericht Biologische Anstalt Helgoland, 1976, 1-95.

Jahresbericht Biologische Anstalt Helgoland, 1977, 1-112.

Jahresbericht Biologische Anstalt Helgoland, 1978, 1-110.

Oppenheimer, C. H., Gunkel, W. \& Gassmann, G., 1977. Microorganisms and hydrocarbons in the North Sea during July-August 1975. - Proc. Oil Spill Conf., Washington, 1977, 593-609. 